\author{
Original article
}

\title{
Bacterioplankton dynamics in the Mondego estuary (Portugal)
}

\author{
P. Bacelar-Nicolau ${ }^{\text {a,c, } *, \text { L.B. Nicolau }}{ }^{\text {b }}$, J.C. Marques ${ }^{\text {c }}$, F. Morgado ${ }^{\text {d }}$, \\ R. Pastorinho ${ }^{\mathrm{d}}$, U.M. Azeiteiro ${ }^{\mathrm{a}, \mathrm{c}}$ \\ ${ }^{a}$ IMAR, Centro Interdisciplinar de Coimbra a/c Departamento de Zoologia, Universidade de Coimbra, 3004-517 Coimbra, Portugal \\ ${ }^{b}$ DataScience Consultores Lda, Tagus Park, Núcleo Central 344, 2780-920 Oeiras Portugal \\ ${ }^{c}$ Universidade Aberta, Rua da Escola Politécnica, 147, 1269-001 Lisbon, Portugal \\ ${ }^{d}$ Departamento de Biologia, Universidade de Aveiro, 3800 Aveiro, Portugal
}

\begin{abstract}
In this work, the density of bacterioplankton and environmental parameters were monitored over a 11 month period (July 1999-June 2000), and also during one tidal cycle (15 June 2000), at two sampling stations, in the estuary of River Mondego. These data were treated by multivariate analyses methods in order to identify the key factors that control the dynamics of the bacterioplankton in the estuary. Bacterial dynamics were dominated by temporal gradients (annual seasons and tide-related) and less by the spatial structure of the estuary. Three main metabolic groups of bacterioplankton—aerobic heterotrophic bacteria, sulphate-reducing bacteria (SRB) and nitrate-reducing bacteria (NRB) - involved in the cycling of organic matter, were present in the water column of the estuary. Their relative abundance depended on the particular physical, chemical and biological environment. The abundance of aerobic heterotrophic bacteria, during the 11 month study, was modelled as a function of nitrate (the most important variable, with a negative effect), temperature, salinity and pH (with positive effects). SRB appeared to be limited to the water-sediment interface, where concentrations of sulphate and POM were greater. A competition between SRB and NRB for carbon has also been suggested.
\end{abstract}

(C) 2003 Éditions scientifiques et médicales Elsevier SAS. All rights reserved.

Keywords: Bacterioplankton dynamics; Environmental parameters; Seasonal variation; Tidal variation

\section{Introduction}

Estuaries are areas of highly variable environmental parameters, and its dynamics are not easily predictable. In fact, it is general knowledge that seasonal cycles in estuaries depend on the temporal occurrence of deliveries of nutrients, the relative magnitudes of the sources, and the demands of the specific groups of organisms present (Valiela, 1995).

Bacteria have a very important role in planktonic marine microbial foodwebs. They comprise an important share of plankton biomass and their activities have a large impact on ecosystem metabolism and function (Gasol and Duarte, 2000), through their roles in the biogeochemical cycles, namely in carbon (Valiela, 1995), sulphur (Fauque, 1995; Valiela, 1995), nitrogen (Herbert, 1999) and iron cycling (Tordell et al., 1999). Determination of the composition of bacterial populations, abundance of each metabolic group, and the discrimination of the different activities is therefore

\footnotetext{
* Corresponding author.

E-mail address: pnicolau@univ-ab.pt (P. Bacelar-Nicolau).
}

essential for understanding pelagic ecology. A lot of effort has been taken towards determining the environmental and biological factors that control the dynamics and activity profiles of bacterioplankton communities, e.g. temperature, nutrient availability, viral infection and bacterial predation (Almeida et al., 2001a, b; Brett et al., 1999; Gasol and Duarte, 2000). Bacterial activity is, however, generally affected by these factors in a concerted manner, in which most studies using bivariate analyses can only provide a fragmented view (Gasol and Duarte, 2000).

The estuary of the Mondego has been extensively described from the point of view of nutrient dynamics (Azeiteiro and Marques, 2000; Lillebø, 2000; Marques et al., 1997; Pardal, 1998) and the composition of estuarine invertebrates communities (Azeiteiro and Marques, 1999; Azeiteiro et al., 1999; Marques et al., 1997; Pardal, 1998). The bacterioplankton only recently have begun to be investigated in this estuary (Bacelar-Nicolau et al., Revista da Biologia (Lisboa) 19: 51-62 (2001)). In this work, we have analysed bacterioplankton abundance and environmental parameter data over a 11 month period (July 1999-June 2000), 
as well as during one tidal period (June 2000), using multivariate statistical methods. This study was aimed at identifying the key factors controlling the dynamics of bacterioplankton in the Mondego estuary, particularly of aerobic heterotrophic bacteria, nitrate-reducing bacteria (NRB) and sulphate-reducing bacteria $(\mathrm{SRB})$; relevant in the overall ecology of the estuary.

\section{Materials and methods}

\subsection{Study site}

The Mondego River, on the western coast of Portugal, drains a hydrological basin of approximately $6.670 \mathrm{~km}^{2}$. The estuary $\left(40^{\circ} 08^{\prime} \mathrm{N} 8^{\circ} 50^{\prime} \mathrm{W}\right)$ has an area of $3.3 \mathrm{~km}^{2}$ and a mean water volume of $0.0075 \mathrm{~km}^{3}$ (Flindt et al., 1997), and consists of two arms that separate at about $7 \mathrm{~km}$ from the sea, and join near the mouth Fig. 1. The estuary has a tidal range 0.35-3.3 $\mathrm{m}$ and an average freshwater discharge of $8.5 \times 10^{9}$ $\mathrm{m}^{3} \mathrm{~s}^{-1}$ (Flindt et al., 1997). The average residence time is $2 \mathrm{~d}$ in the north arm and $9 \mathrm{~d}$ in the south arm (Flindt et al., 1997). Upstream areas of the south arm are almost completely silted up, and consequently, the water circulation depends mainly on tides, and to a small extent on the freshwater discharge from a tributary, Pranto River, that is controlled by a sluice located $3 \mathrm{~km}$ from the confluence with the Mondego (Flindt et al., 1997). Two sampling stations were chosen, located at the south arm of the estuary: station 1 (S1), close to the mouth, and station 2 (S2), located near the Pranto River.

\subsection{Field programme}

Water samples were collected monthly, at high tide, at the water subsurface (ca. $0.3 \mathrm{~m}$ depth) in S1 and S2. Water samples were also collected during one tidal cycle, in both the stations, at about $3 \mathrm{~h}$ intervals, from the water subsurface (ca. $0.3 \mathrm{~m}$ depth) and near-sediment surface $(5-8 \mathrm{~m}$ and 0.5-2 m depth, respectively, for S1 and S2), on 15 June 2000.

\subsection{Determination of physical and chemical parameters}

All the samples were analysed in situ for salinity, temperature, dissolved oxygen, $\mathrm{pH}, E_{\mathrm{h}}$ and conductivity. The samples were also analysed in the laboratory (in triplicate) for their content in dissolved nitrate, nitrite, ammonia, sulphate, phosphate, particulate organic matter and chlorophyll $a$ (Strickland and Parsons, 1972).

\subsection{Sampling procedure and enumeration of viable bacteria}

Water samples (1 1) for the enumeration of viable bacteria were collected in parallel to those obtained for physical and chemical analyses. The samples were collected into sterile glass flasks, filled to capacity, sealed with gas-tight rubber stoppers and immediately placed on ice until processing was initiated in the laboratory (12-24 h later).

The numbers of viable aerobic chemoorganotrophic bacteria, SRB and NRB were estimated through the Most Probable Number (MPN) method. Three or five replicates of series of 10-fold water dilutions, in appropriate selective liquid media (see below), were prepared in multiwell plates. Cultures were incubated at $37^{\circ} \mathrm{C}$, in the dark, for 3 weeks (aerobes) or 6 weeks (anaerobes). The presence of bacteria was scored positive on the basis of turbidity or precipitate development, and confirmed by microscopic observation.

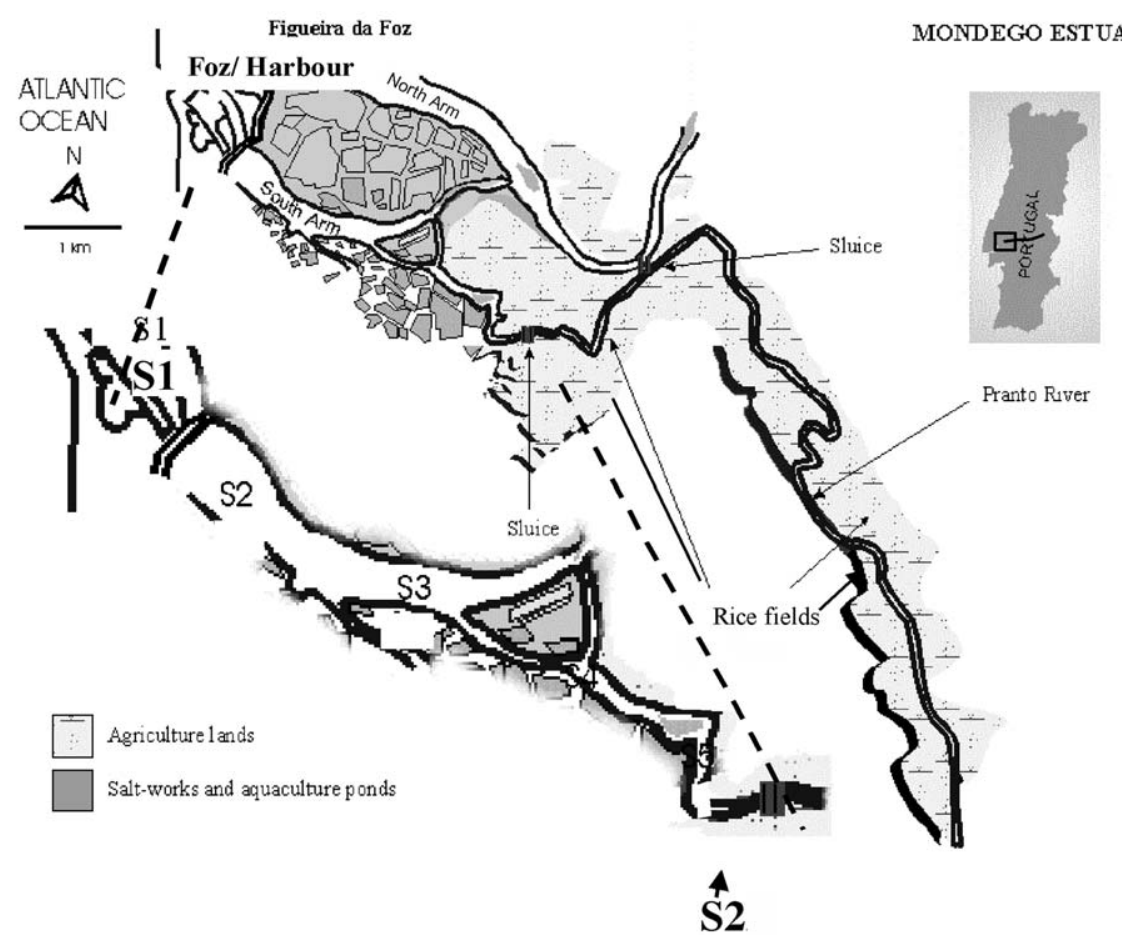

Fig. 1. Map of the Mondego estuary showing the locations of the two sampling stations in the south arm. 
The growth of SRB and NRB required strict anaerobic procedures that were used at all times (Widdel and Bak, 1992).

The growth media used throughout this study were selected from preliminary experiments (Bacelar-Nicolau et al., Revista da Biologia (Lisboa) 19: 51-62 (2001)). YPG medium containing yeast extract $\left(2 \mathrm{~g} \cdot \mathrm{l}^{-1}\right)$, bacto peptone $\left(1 \mathrm{~g} \cdot \mathrm{l}^{-1}\right)$ and glucose $\left(2 \mathrm{~g} \cdot \mathrm{l}^{-1}\right)$ was used for the growth of aerobic heterotrophic bacteria. An SRB growth medium was used containing basal salts, trace elements, vitamins, lactate $(20 \mathrm{mM})$ as an electron donor and carbon source, and sulphate $\left(\mathrm{Na}_{2} \mathrm{SO}_{4}, 20 \mathrm{mM}\right)$ was used as the terminal electron acceptor (Beech and Vitalis, unpublished). The saltwater Widdel and Bak multipurpose medium (Widdel and Bak, 1992) was used for the growth of NRB, adding nitrate $\left(\mathrm{NaNO}_{3}, 10 \mathrm{mM}\right)$ instead of sulphate as the terminal electron acceptor; lactate was also added $(20 \mathrm{mM})$. The concentration of $\mathrm{NaCl}$ was adjusted to the average salinity of the estuary $\left(20 \mathrm{~g} \cdot \mathrm{l}^{-1}\right)$. The $\mathrm{pH}$ was adjusted to 7 prior to autoclaving, in all media.

\subsection{Statistical analysis}

All the variables were normalised by logarithmic transformation. Pearson correlation analysis was used to assess major linear relations between variables. Principal component analysis (PCA) (SPAD 3.5, Cisia-Ceresta) was applied to identify the major sources of variability in the bacterial communities in both time scale studies. Stepwise multivariate linear regression (LEASP; Bacelar-Nicolau et al., 1998) was applied to find an explanatory model for the dynamics of the heterotrophic bacterial community in terms of the environmental parameters (temperature, $\mathrm{pH}, E_{\mathrm{h}}, \mathrm{dO}_{2}$, total $\mathrm{N}$, $\mathrm{NO}_{3}{ }^{-}, \mathrm{NH}_{3}, \mathrm{NO}_{2}{ }^{-}, \mathrm{SO}_{4}{ }^{2-}, \mathrm{N} / \mathrm{P}$, chlorophyll $a$ ) during the period between July 1999 and June 2000.

\section{Results}

\subsection{Annual study}

The variation patterns of the environmental and biological parameters, at each station at high tide, are shown in Figs. 2 and 3. Water temperature showed a unimodal pattern at both the stations, with maxima in summer and minima in winter Fig. 2a. The temperature values were greater at S2 in spring and summer, reflecting the seasonal changes at this shallow estuarine station. Most of the other parameters were affected by the discharges from the Pranto River: the sluice, which usually opens during winter was, in the studied period, also open in April 2000, resulting in bimodal annual patterns, instead of the usual unimodal patterns (Azeiteiro and Marques, 2000). The $\mathrm{pH}$ values were fairly constant during the studied period with maxima in January and June 2000, (a)

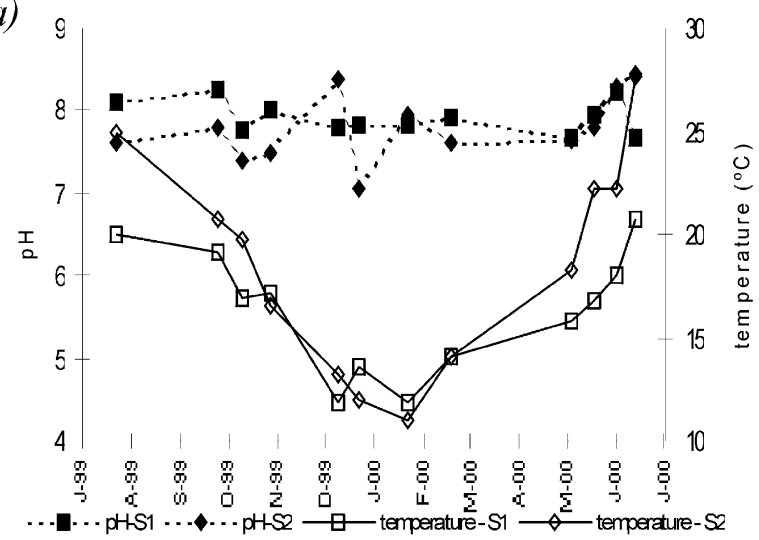

(c)

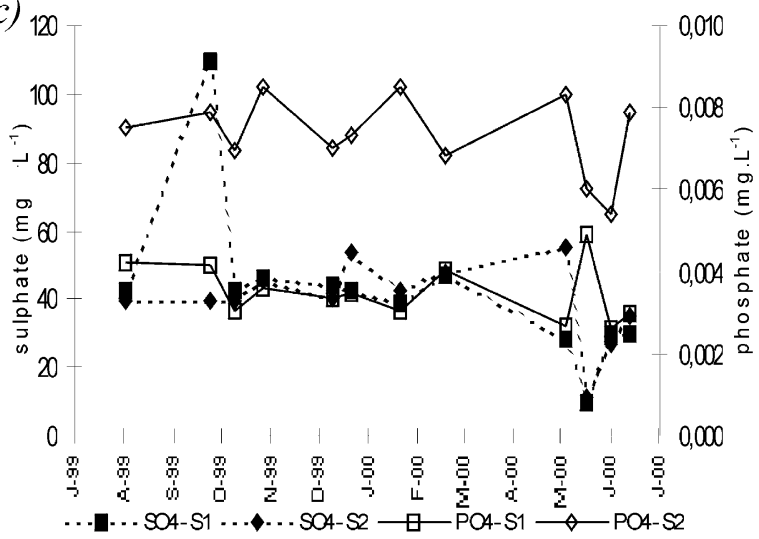

(b) $\infty$

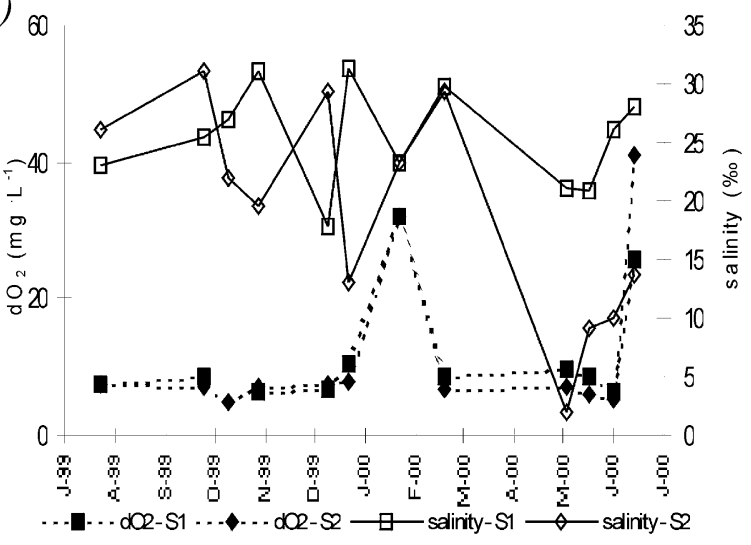

(d)

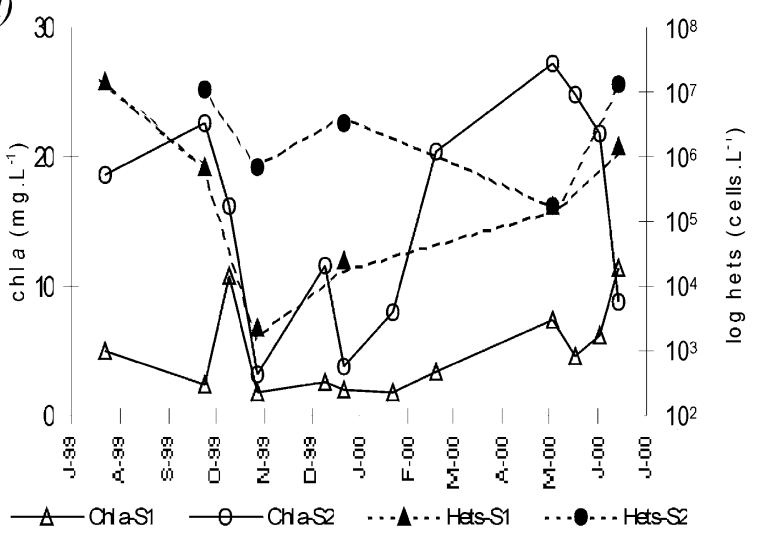

Fig. 2. Physicochemical and biological variables of the water column, at high tide, in S1 and S2 (July 1999-June 2000): (a) pH, temperature, (b) dissolved oxygen, salinity, (c) sulphate, phosphate, (d) chlorophyll $a$ and aerobic heterotrophic bacteria. 
(a)

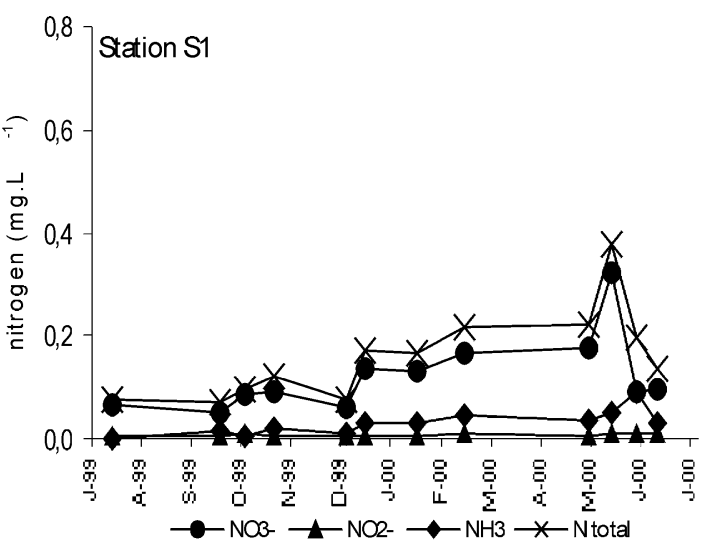

(b)

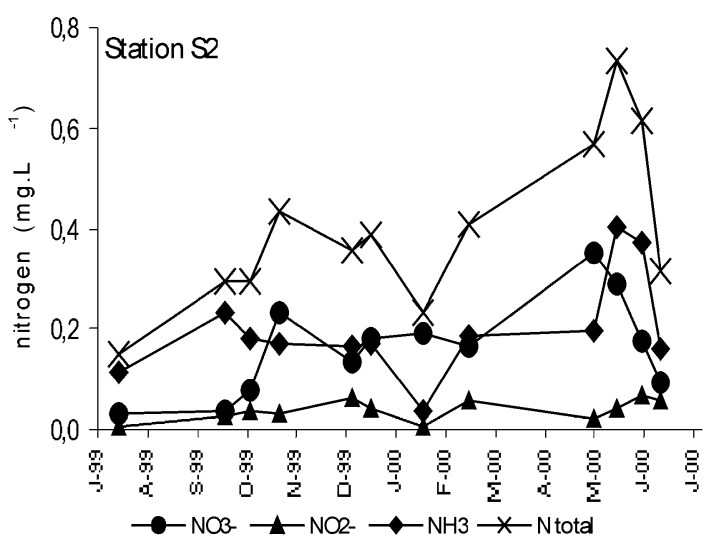

Fig. 3. Variation of nitrogen compounds (total N, nitrate, nitrite, ammonia) in the water column, at high tide, in S1 and S2 (July 1999-June 2000).

specifically at S2 Fig. 2a. Salinity values showed considerable variation with minima in January and May 2000, in particular at $\mathrm{S} 2 \mathrm{Fig}$. 2b. Dissolved oxygen $\left(\mathrm{dO}_{2}\right)$ was fairly constant throughout the year, reaching maxima values in January and June 2000 Fig. 2b. The concentration of sulphate was fairly constant at S1 and S2 during the studied period, except for a maximum value in September 1999 at S1, and a minimum in May 2000 at both the stations Fig. 2c. Phosphate concentration was always greater at station $\mathrm{S} 2$ than that at $\mathrm{S} 1$ Fig. 2c). The concentration of total nitrogen was also greater at S2 (nearly three fold) than S1, particularly from September till December 1999, and in June 2000 Fig. 3a b), although the three monitored nitrogen compounds differed, in their relative abundance, at the two stations $\left(\mathrm{NO}_{3}{ }^{-}, \mathrm{NH}_{3}\right.$ and $\mathrm{NO}_{2}{ }^{-}$represented, respectively, $77 \%$, $18 \%$ and $6 \%$ of the total nitrogen at S1, whilst they were $40 \%, 50 \%$ and $10 \%$, respectively, at S2). Nitrate concentration was fairly similar at S1 and S2, except during the summer of 1999, when the nitrate level at S1 nearly doubled that at S2. Nitrite and ammonia showed similar variation patterns at the two stations (except for the summer of 1999), although their concentrations at S1 were generally ca. $10-20 \%$ of those at S2 (levels of nitrite and ammonia were similar in January 2000).

The concentration of chlorophyll $a$ was, in most cases, higher at S2 than at S1 Fig. 2d. Chlorophyll $a$ exhibited a bimodal pattern with maxima during autumn (1999) and spring (2000). Viable counts of aerobic heterotrophic bacteria Fig. 2d showed a unimodal pattern, with maxima values in summer and minimum values in winter at $\mathrm{S} 1$, although this was not so clear at $\mathrm{S} 2$, where bacterial numbers were greater. NRB and SRB were also detected although their enumeration was only performed between December 1999 and June 2000 (not shown). In brief, duringthat period, NRB ranged between $4.6 \times 10^{5}$ and $1.1 \times 10^{7}$ cells. $\mathrm{l}^{-1}$, and SRB ranged between $3.0 \times 10^{3}$ and $4.6 \times 10^{5}$ cells. $1^{-1}$. Also, bacterial numbers for each metabolic group were greater at $\mathrm{S} 2$ than $\mathrm{S} 1$. The PCA of the environmental and biological factors vs. samples (station and date) matrix, taking into account the first three axes, explained $69.25 \%$ of data variability Fig. 4 .
The first axis (PC1; 43.89\%) revealed a strong opposition between the two sampling stations, therefore defining a spatial gradient: samples characterised by greater levels of total nitrogen, ammonia, nitrite, chlorophyll $a$, phosphate and temperature largely corresponded to those from S2, while samples characterised by higher salinity corresponded to those from S1. The second axis of variability (PC2; 14.67\%) opposed samples characterised by higher levels of sulphate and salinity, mostly collected during autumn 1999 (mostly at S2), and samples characterised by higher levels of nitrate, $\mathrm{dO}_{2}$ and $\mathrm{pH}$, which correspond mostly to those collected in spring 2000 (mainly May). The third axis of variability (PC3; $10.69 \%$ ) defined an opposition between the samples characterised by higher levels of temperature, $\mathrm{pH}$ and counts of aerobic heterotrophic bacteria, corresponding to samples mostly collected during summer, and samples characterised by higher levels of nitrate, corresponding to samples collected in winter 1999 and spring 2000. Therefore, the second and third factors defined two distinct temporal gradients (autumn vs. spring; and winter/spring vs. summer). Multiple linear regression analysis of the environmental and biological (aerobic heterotrophic bacteria) variables vs. sample matrix indicated that the density variation of the aerobic heterotrophic bacteria (for the period July 1999 till June 2000) was explained by the interaction of the following four environmental parameters: nitrate, salinity, $\mathrm{pH}$ and temperature Table 1). The multiple linear regression analysis $(r=0.875$; $\left.r^{2}=0.766\right)$ indicated that the number of heterotrophic bacteria increases with increasing temperature, and decreases with increasing levels of nitrate, salinity and $\mathrm{pH}$.

\subsection{Tidal study}

Variation patterns of the environmental parameters, at each station and depth, during the tidal cycle are shown in Fig. 5 Most parameters were clearly influenced by the tidal flux. At station S1, the effect of saline intrusion was observed in the fluctuations of salinity, conductivity, $E_{\mathrm{h}}$ and $\mathrm{dO}_{2}$, and a dilution effect was observed in the variation of temperature, $\mathrm{pH}$, phosphate, nitrite, POM and chlorophyll $a$. At station S2, 

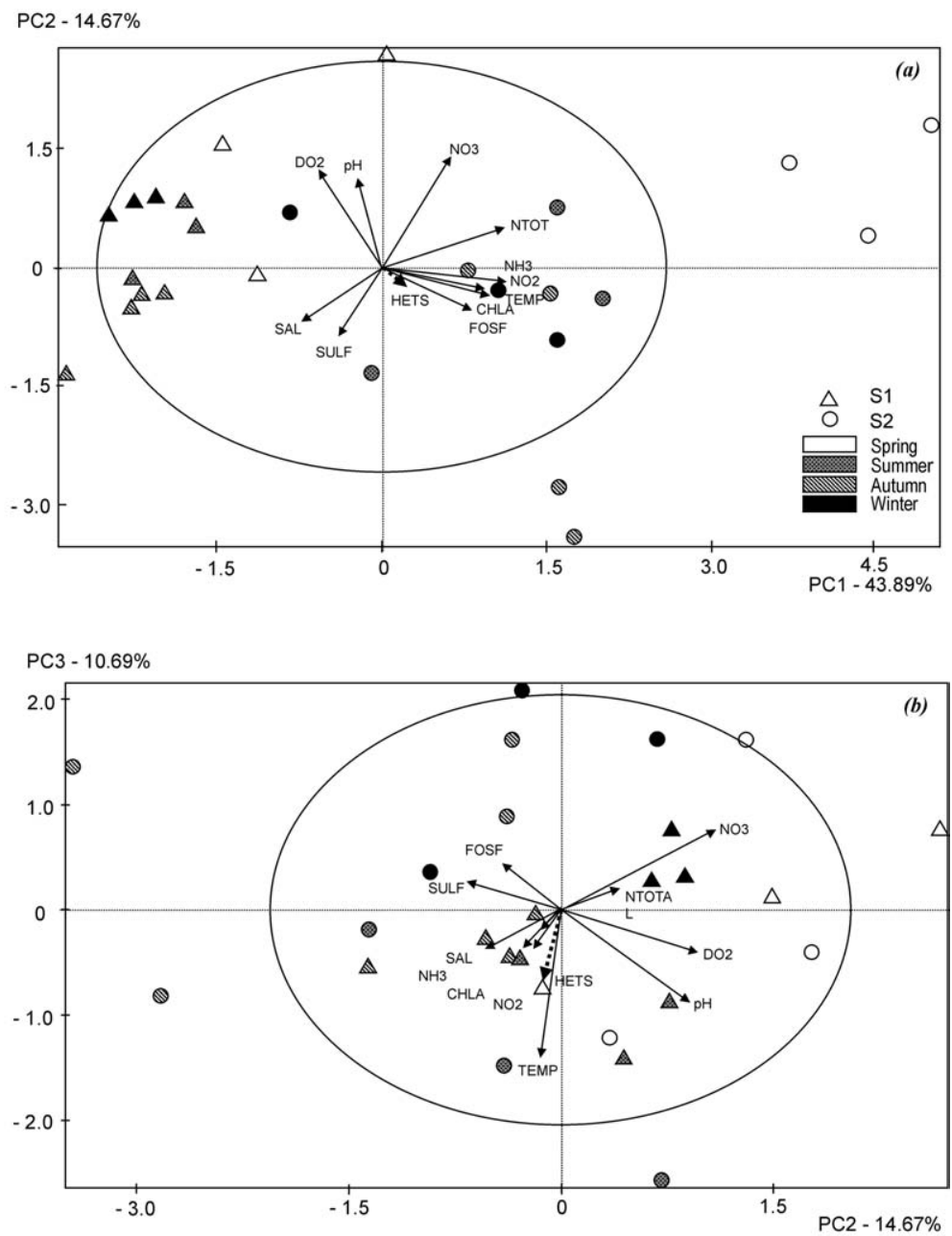

Fig. 4. Projection of the principal components 1, 2 and 3 (PC1, PC2 and PC3) for the PCA of physical, chemical and biological factors vs. sample matrix during the period July 1999-June 2000 (SPAD 3.5, Cisia-Ceresta). Descriptors: salinity (SAL), temperature (TEMP), pH (pH), dissolved oxygen (DO2), total nitrogen (NTOT), nitrate $\left(\mathrm{NO}_{3}\right)$, nitrite $\left(\mathrm{NO}_{2}\right)$, ammonia $\left(\mathrm{NH}_{3}\right)$, phosphate (FOSF), sulphate (SULF), chlorophyll $a(\mathrm{CHLA})$ and aerobic heterotrophic bacteria (HETS).

the effect of tidal intrusion was also observed in salinity, conductivity, sulphate and phosphate levels, and $E_{\mathrm{h}}$ (the latter, only at the surface water); a dilution effect was observed on POM and chlorophyll $a$. The different patterns for temperature at S2, when compared to S1 (especially prominent at the surface water), certainly reflected the time of day at which sampling took place (between 9.15 a.m. and 18.10 p.m.). The somewhat peculiar patterns of $E h, \mathrm{dO}_{2}$ and $\mathrm{pH}$, at the surface water in station $\mathrm{S} 2$, could be related to the fact that there was a small but continuous input of freshwater (Pranto River) through leakage over the sluice. The tributary

Table 1

Variables in the equation of multiple regression for the variation of the abundance of aerobic heterotrophic bacteria over the 11 month period (LEASP; Bacelar-Nicolau et al., 1998); $r=0.875 ; r^{2}=0.766$

\begin{tabular}{lll}
\hline Variables & $\begin{array}{l}\text { Regression } \\
\text { coefficient }\end{array}$ & $\begin{array}{l}\text { Standard deviation of the } \\
\text { regression coefficient }\end{array}$ \\
\hline Nitrate & -15.056 & 3.0631 \\
Salinity & -0.125 & 0.0282 \\
$\mathrm{pH}$ & -2.112 & 0.5031 \\
Temperature & 0.1391 & 0.0529 \\
Constant & 24.510 & \\
\hline
\end{tabular}

river receives water that leaches highly fertilised, iron-rich agricultural fields and this could affect the phosphate and ionic dynamics of the receiving stream (M.J. Pereira, pers. com.), and be responsible for the distinct patterns observed at the surface and near-sediment water at S2.

Bacterial numbers Fig. 6 were also influenced by tidal fluxes. The numbers of aerobic heterotrophic bacteria exhibited a dilution affect, especially at S1, decreasing with flood tide and increasing with ebb tide. SRB were only detected in samples collected near the sediment, duringebb tide at S1 and at high tide at $\mathrm{S} 2$. The number of NRB (not shown) was always greater than $2.4 \times 10^{6}$ cells $\cdot 1^{-1}$ at all the studied sites.

The first three principal components defined by the PCA of environmental and biological factors vs. samples matrix, explained $80.82 \%$ of the tidal data variability. The first axis $(45.29 \%)$ revealed a strong opposition between the two sampling stations (irrespective of depth; Fig. 7a, defining a spatial gradient: samples characterised by higher levels of phosphate, nitrite, temperature, $E_{\mathrm{h}}, \mathrm{pH}$, total nitrogen and POM, largely corresponded to those collected at S2, while samples characterised by higher salinity and conductivity 

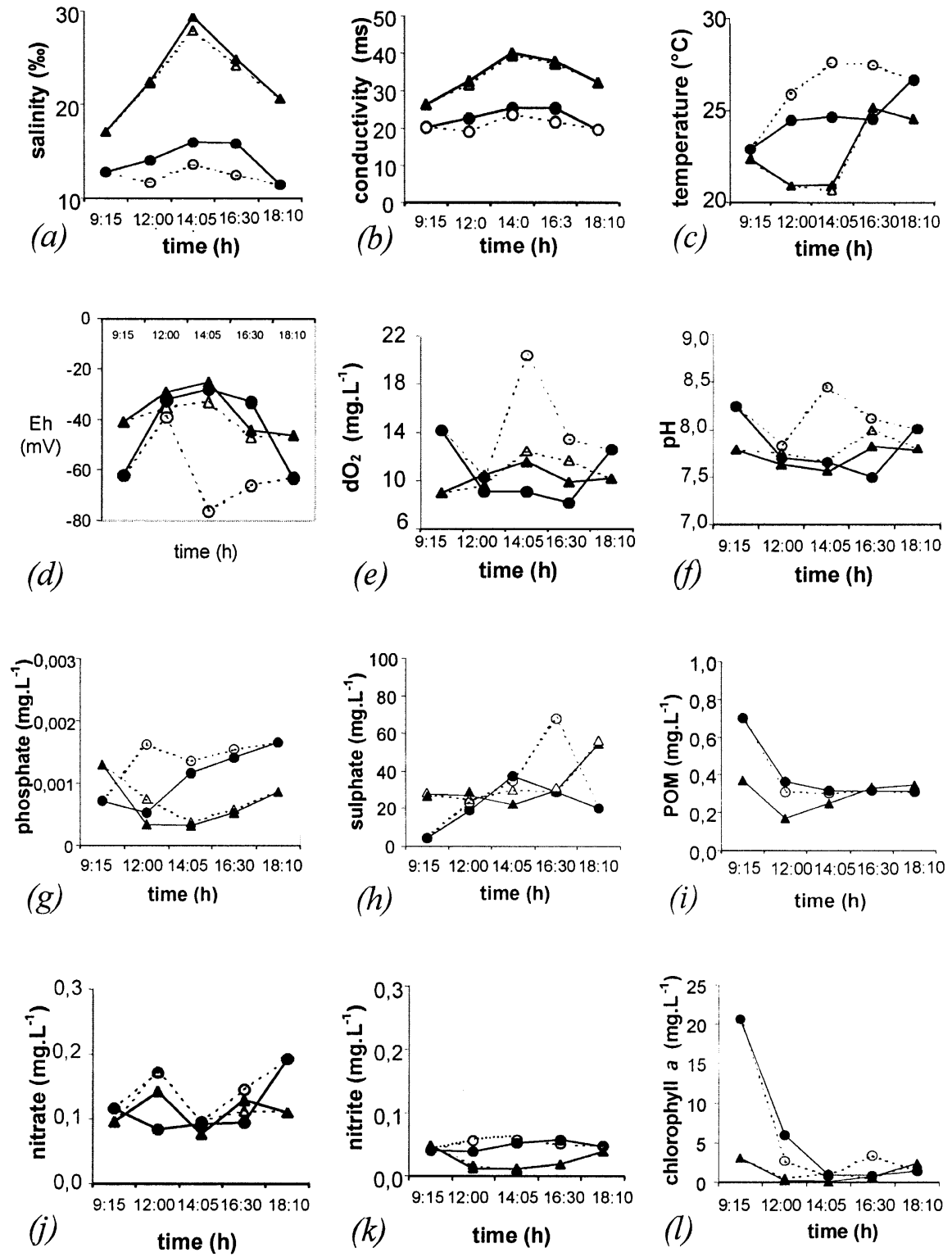

Fig. 5. Variation of physicochemical and biological parameters at S1 and S2 during one tidal cycle (15 June 2000). High tide was at 14 h:05 min ( $\Delta$ ) S1, surface water, (\) S1, water-sediment interface, (O) S2, surface water, $(\bullet)$ S2, water-sediment interface.

corresponded to those from S1. The second axis (20.18\%) clearly defined an opposition between the samples collected at S2, near the sediment and those collected at low tide, which are characterised by higher levels of chlorophyll $a$, POM, total nitrogen and aerobic heterotrophic bacterial counts, and all other samples, characterised by higher levels
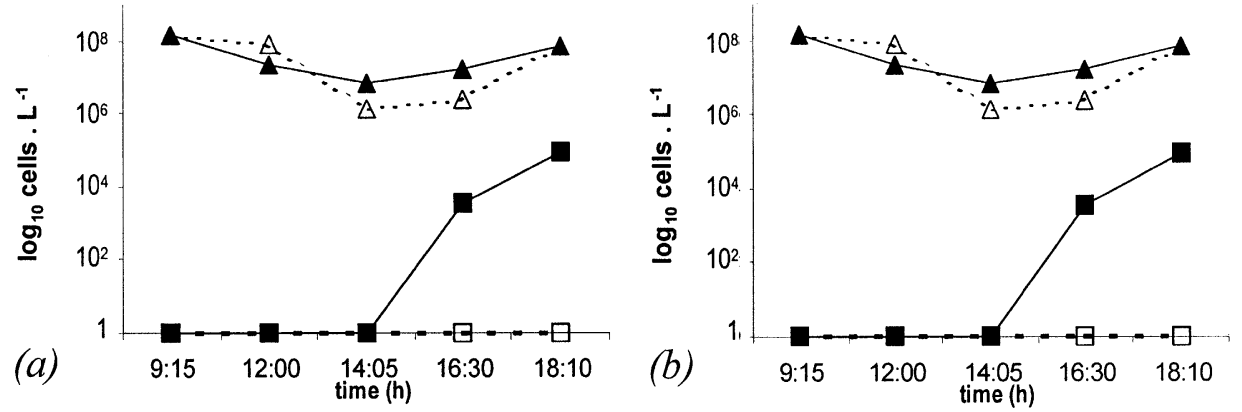

Fig. 6. Bacterial variation at S1 and S2 during one tidal cycle (15 June 2000). High tide was at 14 h:05 min ( $\square$ ) aerobic heterotrophic bacteria, water-sediment interface, $(\square)$ aerobic heterotrophic bacteria, surface water, $(\boldsymbol{\Delta}) \mathrm{SRB}$, water-sediment interface, $(\Delta) \mathrm{SRB}$, surface water. 
PC2 - 20.18\%
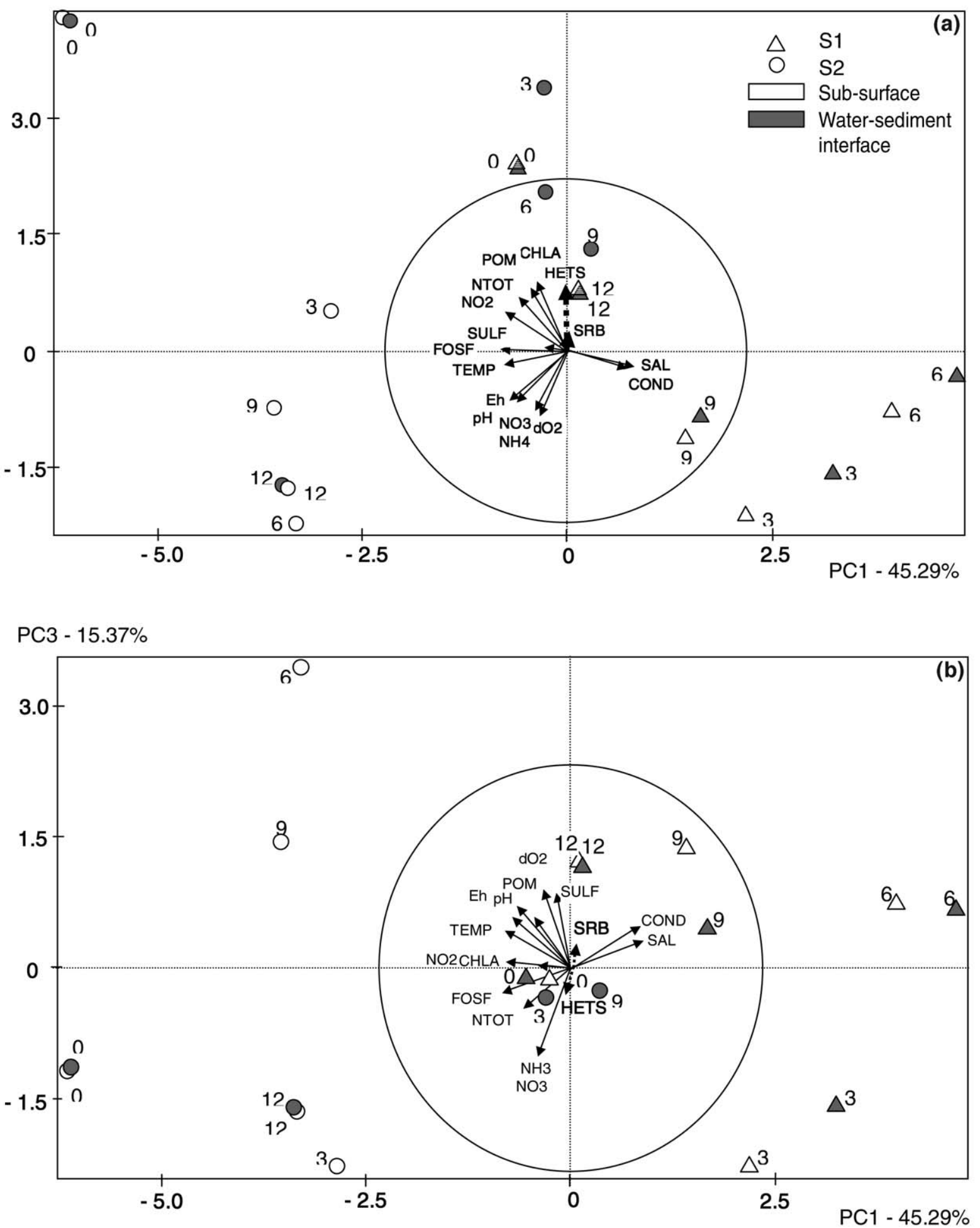

Fig. 7. Projection of the (a) principal components 1 and 2 (PC1 and PC2) and (b) principal components 1 and 3 (PC1 and PC3), for the PCA of physical, chemical and biological factors vs. sample matrix during the tidal cycle on 15th June 1999 (SPAD 3.5, Cisia-Ceresta). Descriptors: salinity (SAL), conductivity (COND), temperature (TEMP), $\mathrm{pH}(\mathrm{pH}), E_{\mathrm{h}}(\mathrm{Eh})$, dissolved oxygen (DO2), nitrate $\left(\mathrm{NO}_{3}\right)$, nitrite $\left(\mathrm{NO}_{2}\right)$, ammonia $\left(\mathrm{NH}_{3}\right)$, total nitrogen (NTOT), sulphate (SULF), phosphate (FOSF), chlorophyll $a$ (CHLA), aerobic heterotrophic bacteria (HETS), and SRB (SRB). Numbers 0, 3, 6, 9, 12 correspond to sampling times, respectively, 9:15, 12:00, 14:05, 16:30 and 18:10. 
of $\mathrm{dO}_{2}$, nitrate and ammonia. The third principal factor $(15.37 \%)$ recognised an opposition between the samples collected during flood tide, characterised by higher levels of nitrate and ammonia, and samples collected during ebb tide, characterised by higher levels of sulphate and $\mathrm{dO}_{2}$ Fig. 7b.

\section{Discussion}

Our results indicate that bacterial dynamics are mainly affected by temporal gradients (annual seasons, and tiderelated gradients), and less by the spatial structure of the Mondego estuary in both the time scale studies.

The three metabolic groups of bacteria were present in the estuary, although we were only able to model the dynamics of aerobic heterotrophic bacteria (due to insufficient data). The abundance of aerobic heterotrophic bacteria during the quasiannual period was modelled as a function of four parameters, that dictate its increase with increasing temperature (as found by other authors Cunha et al., 2000; Ducklow and Shiah, 1993; Hoch and Kirchman, 1993), but decreasing with $\mathrm{pH}$, salinity and nitrate (the latter being the most important variable). Hence, the biogeochemical cycle of nitrogen is central for understanding the overall dynamics of the south arm of the Mondego estuary. The high input of nitrogen as nitrate, at S2, from the Pranto River, resulted in a localised increase of phytoplankton (chlorophyll $a$ ) abundance, which led to an increase of ammonia concentration (resulting from excretion or biomass degradation (Valiela, 1995). This in turn led to eutrophication and depletion of $\mathrm{dO}_{2}$. Under these conditions, aerobic heterotrophic bacteria would be inhibited, as evidenced by the multiple regression analysis. Under the same set of conditions, microbial denitrification may occur with the production of ammonia (via hydroxylamine intermediates) or nitrite (Herbert, 1999; Zumft, 1997), as observed particularly at $\mathbf{S} 2$. These observations are also supported by the positive correlation of total N, ammonia and nitrite with chlorophyll $a$, and the negative correlation of ammonia with $\mathrm{dO}_{2}$. NRB were detected during the tidal study on 15 June 2000 and on previous counting experiments, even though denitrifying activity by NRB and their contribution to the ammonia production was not quantified.

Phosphorus (as phosphate) was apparently of less importance to the bacterial community, even though some authors have emphasised that it can be the limiting resource for bacterioplankton (Currie, 1990; Rivkin and Anderson, 1997). It appeared, however, to be limiting to the phytoplankton, as suggested by the positive correlation between the two variables, and by the fact that the ratio $\mathrm{N}: \mathrm{P}$ was above the Redfield ratio value (N:P values ranged 17.2-81.1 and 20.1-122.5, respectively, at S1 and S2), throughout the study period. The analysis of the tidal data further showed a very strong positive correlation of phosphate with nitrite and temperature. Phosphate in water and sediments is, to a large extent, determined by biological activity (Valiela, 1995) and therefore dissimilative reactions, including nitrate reduction, result in the regeneration of phosphorus (supported by the tidal variation). This process is temperature dependent both because increasing temperature increases microbial nitrate reduction, and also because temperature (representing light intensity) indirectly induces the anaerobic conditions necessary for nitrate reduction via the blooms of primary producers (Pardal, 1998). These correlations are mostly evident in the tidal scale study, because it focuses on the short scale, on-going, metabolic processes. In marine environments, particularly in aerobic conditions, sulphate is the most abundant form of sulphur. The reduction of sulphate to sulphide, under an anaerobic environment, depends on factors, such as diffusion and availability of organic matter. In the presence of oxygen or nitrate, sulphide is in turn oxidised chemically and biologically to more oxidised forms of sulphur, including sulphate (Valiela, 1995). In the estuary of the Mondego, sulphate dynamics are strongly linked to nitrogen dynamics as evidenced by the negative correlation of sulphate with nitrate (both the time scale studies) as well as with total nitrogen, ammonia and nitrite (annual study). Also, the PC analyses for both the time scale studies revealed a clear opposition between samples with higher levels of sulphate (mostlysummer months or ebb tide) and those with higher nitrate levels (mostly spring months or flood tide). This might be partly explained by the presence of SRB (detected, although in low numbers, during the tidal study), as these bacteria are active mostly under the anaerobic conditions produced by the input of high levels of nitrogen in the estuary. The numbers of SRB were closely related to the concentration of sulphate (and supported by PC3; BacelarNicolau et al., in press) and POM. The fluctuation of SRB and sulphate concentration in this case appeared to result from sediment resuspension induced by the water influx and outflow during the tidal study, as they coincided with high tide at S2, and ebb tide at S1. The opposition nitrate vs. sulphate revealed by the two PCAs, moreover, suggests a competition between SRB and NRB for carbon resources in the estuary. This may, however, be limited to the watersediment interface, where both groups of bacteria are most active (Herbert, 1999; Teske et al., 1998), and where the supply of organic matter increases, as suggested by PC3 (Sampou and Oviatt, 1991).

Phytoplankton and heterotrophic bacterioplankton are often closely related in aquatic systems, less clearly in estuaries where the allochthonous supply of organic matter is appreciable (Chatila et al., 1999; Ducklow, 1999; Jugnia et al., 1999). In both our studies, a close relationship was observed between phytoplankton (chlorophyll $a$ ) and aerobic heterotrophic bacteria. In addition, for the tidal period, PC2 revealed a close relationship between POM, phytoplankton and aerobic heterotrophic bacteria, as well as a strong opposition between those three variables and levels of $\mathrm{dO}_{2}$. These results, therefore suggest that the fluctuation of organic matter in the south arm of the estuary may be mainly due to phytoplankton metabolism. They also indicate a strong reliance of the aerobic heterotrophic bacterial abundance on in situ plankton metabolism, as observed in the Chesapeake 
Bay (Ducklow et al., 1999). The population of aerobic heterotrophic bacteria would thus utilise carbon resources and oxygen, or use carbon resources under low $\mathrm{dO}_{2}$ conditions (Bacelar-Nicolau et al., Revista da Biologia (Lisboa) 19: 51-62 (2001)). Under these conditions, NRB activity may be of great relevance in the cycling of carbon, particularly at S2 (supported by the levels of nitrite, the positive correlation of POM and nitrite, and by the PCA of tidal data).

Our data thus support the hypothesis that the relative importance of each of the three metabolic groups of heterotrophic bacteria to the carbon cycling in the water column of the Mondego estuary depends on the particular physical, chemical and biological environment. Nitrate appeared to be the most important key parameter controlling the profiles of heterotrophic bacteria, with a negative effect on aerobic bacteria (and suggestively positive on NRB), although temperature, $\mathrm{pH}$ and salinity also affected the system. SRB may be of relevance to the system at the water-sediment interface, where sulphate and POM are more abundant.

\section{Acknowledgements}

The authors wish to thank Professor F. Nicolau for support in multivariate data analyses, and Dr. A.R. Lino for the laboratory facilities for the microbiological work.

\section{References}

Almeida, M.A., Cunha, M.A., Alcântara, F., 2001. a. Factors influencing bacterial production in a shallow estuarine system. Microbial Ecology 42, 416-426.

Almeida, M.A., Cunha, M.A., Alcântara, F., 2001. b. Loss of estuarine bacteria by viral infection and predation in microcosm conditions. Microbial Ecology 42, 562-571.

Azeiteiro, U.M.M., Marques, J.C., 1999. Temporal and spatial structure in the suprabenthic community of a shallow estuary (Western Portugal: Mondego estuary. Acta Oecologica 20, 333-342.

Azeiteiro, U.M.M., Marques, J.C., 2000. Variação espácio-temporal dos parâmetros ambientais (condições físico-químicas da água e nutrientes) no estuário do Mondego (Costa Ocidental de Portugal). In: Da Costa Duarte, A., Vale, C., Prego, R. (Eds.), Estudos de Biogeoquímica na Zona Costeira Ibérica. Publicações da Universidade de Aveiro, Portugal, pp. 301-316.

Azeiteiro, U.M.M., Jesus, L., Marques, J.C., 1999. Distribution, population dynamics and production of the suprabenthic mysid Mesopodopsis slabberi van Beneden in the Mondego estuary (Western coast of Portugal. Journal of Crustacean Biology 19, 498-509.

Bacelar-Nicolau, H., Nicolau, F., Dias, O., Ramos, L., 1998. LEASP97: an improvement in teaching and analysing new methodology on probabilistic clustering models. In: Proceedings of the Fifth International Conference on Teaching of Statistics-ICOTS-5, Singapore. pp. 863-869.

Bacelar-Nicolau, P., Marques, J.C., Morgado, F., Pastorinho, R., Nicolau, L.B., Azeiteiro, U.M., 2001. Tide-induced variations in the bacterial community, and in the physical and chemical properties of the water column of the Mondego estuary. Revista da Biologia (Lisboa) 19, 51-62.

Brett, M.T., Lubnow, F.S., Villar-Argaiz, M., Goldman, C.R., 1999. Nutrient control of bacterioplankton and phytoplankton dynamics. Aquatic Ecology 33, 135-145.

Chatila, K., Demers, S., Mostajir, B., Chanut, J.P., Monfort, P., 1999. An endogenous periodicity exhibited in the activity of a natural bacterioplankton community isolated in mesocosms. Canadian Journal of Microbiology 45, 555-564.
Cunha, M.A., Almeida, M.A., Alcântara, F., 2000. Patterns of ectoenzymatic and heterotrophic bacterial activities along a salinity gradient in a shallow tidal estuary. Marine Ecology Progress Series 204, 1-12.

Currie, D.J., 1990. Large-scale variabilityand interactions among phytoplankton, bacterioplankton, and phosphorous. Limnologyand Oceanography 35, 1437-1455.

Ducklow, H.W., 1999. The bacterial component of the oceanic euphotic zone. FEMS Microbiology Ecology 30, 1-10.

Ducklow, H.W, Shiah, F.K., 1993. Estuarine bacterial production. In: Ford, T. (Ed.), Aquatic Microbiology: An ecological approach. Blackwell, London, pp. 261-264.

Ducklow, H.W., Schultz, G., Raymond, P., Bauer, J., Shiah, F.K., 1999. In: Bell, C.R., Brylinsky, M., Johnson-Green, P. (Eds.), Bacterial dynamics in large and small estuaries. Microbial Biosystems: New Frontiers, Proceedings of the Eighth International Symposium on Microbial Ecology, Atlantic Canada Society for Microbial Ecology. Halifax, Canada.

Fauque, G.D., 1995. Ecology of sulfate-reducing bacteria. In: Barton, L.L. (Ed.), Sulfate-Reducing Bacteria. Plenum Press, New York, pp. 217-241.

Flindt, M.R., Kamp-Nielsen, L., Marques, J.C., Pardal, M.A., Bocci, M., Bendoricchio, G., et al., 1997. Description and comparison of three shallow estuaries: Mondego River (Portugal), Roskield Fjord (Denmark) and the lagoon of Venice (Italy). Ecological Modelling 102, 17-31.

Gasol, J.M., Duarte, C.M., 2000. Comparative analyses in aquatic microbial ecology: How far do they go? FEMS Microbiology Ecology 31, 99-106.

Herbert, R.A., 1999. Nitrogen cycling in coastal marine ecosystems. FEMS Microbiology Ecology 23, 563-590.

Hoch, M.P., Kirchman, D.L., 1993. Seasonal and interannual variability in bacterial production and biomass in a temperate estuary. Marine Ecology Progress Series 98, 283-295.

Jugnia, L.B., Tadonleke, R.D., Siime-Ngando, T., Devaux, J., Andrivon, C., 1999. Bacterial population dynamics, production, and heterotrophic activity in a recently formed reservoir. Canadian Journal of Microbiology 45, 747-753.

Lillebø, A.I., 2000. The effect of salt marshes plants on the nutrient dynamics in the Mondego estuary (Portugal). PhD Thesis, Universidade de Coimbra, Portugal. pp. 180.

Marques, J.C., Pardal, M.A., Nielsen, S.N., Jorgensen, S.E., 1997. Analysis of the properties of exergy and biodiversity along an estuarine gradient of eutrophication. Ecological Modelling 102, 155-167.

Pardal, M.A.C., 1998. Impacto da Eutrofização nas Comunidades Macrobentónicas do Braço Sul do Estuário do Mondego (Portugal). PhD Thesis, Universidade de Coimbra, Portugal. pp. 315.

Rivkin, R.B., Anderson, M.R., 1997. Inorganic nutrient limitation of oceanic bacterioplankton. Limnology and Oceanography 42, 730-740.

Sampou, P., Oviatt, C.A., 1991. A carbon budget for a eutrophic marine ecosystem and the role of sulfur metabolism in sedimentary carbon, oxygen, and energy dynamics. Journal of Marine Research 49, 825-844.

Strickland, J.D., Parsons, T.R., 1972. A practical hand-book of seawater analysis. Bulletin of Fisheries Research Bd. Canada 167, 1-311.

Teske, A., Ramsing, N.B., Habitch, K., Fukui, M., Kuver, J., Jørgensen, B.B., Cohen, Y., 1998. Sulfate-reducing bacteria and their activities in cyanobacterial mats of Solar lake (Sinai, Egypt). Microbiology 64. Applied and Environmental, 2943-2951.

Tordell, P.D., Maldonado, M.T., Granger, J., Price, N.M., 1999. Marine bacteria and biogeochemical cycling of iron in the oceans. FEMS Microbiology Ecology 29, 1-11.

Valiela, I., 1995. Marine Ecological Processes. second ed. Springer-Verlag, New York 686 p.

Widdel, F., Bak, F., 1992. Gram-negative mesophilic sulfate-reducing bacteria. In: Balows, A., Truper, H.G., Dworkin, M., Harder, W., Schleider, K.H. (Eds.), The Prokaryotes, vol. 4. Springer, New York, pp. 3352-3378.

Zumft, W.G., 1997. Cell biology and molecular basis of denitrification. Microbiology and Molecular Biology Reviews 61, 533-616. 